\title{
An innovative Model of Training and Collaboration in the Mining Sector
}

\author{
Morou François OUEDRAOGO ${ }^{1}$, Wilfried $\mathrm{TOE}^{2}$, Luc SIEBENALLER ${ }^{3}$, Mark JESSELL ${ }^{4}$ \\ \{mfo.ttg@gmail.com1, wilfried.toe@asdm.lu2, luc.siebenaller@asdm.lu3, mark.jessell@uwa.edu.au4\} \\ Institut Teng-Tuuma Geosciences de Ouagadougou (ITTGO), 09 BP 859 Ouagadougou 09, Ouagadougou, Burkina Faso ${ }^{1}$. \\ ONG-D «Le Soleil dans la Main » Burkina, ASBL, 09 BP 908 Ouagadougou 09, Burkina Faso ${ }^{2}$. \\ ONG-D «Le Soleil dans la Main », ASBL, 48, Duerfstrooss, L-9696 Winseler, Luxembourg 3. \\ Centre for Exploration Targeting, School of Earth Sciences, The University of Western Australia, 35 Stirling Highway, \\ Crawley, WA, 6009, Australia. ${ }^{4}$
}

\begin{abstract}
To date, education and training in the mining sector in Burkina Faso is quite "theoretical" because of certain limiting factors. Several recommendations and projects try to answer the mismatch between research, training and jobs. The "railway model" proposed here presents the possibility of applying a new mode of collaboration between the different actors in sustainable development in the applied geosciences. This is the necessary match between "Applied Research" and "Operational Geology". This model of education and training can only be carried out by trainers who have together mining intelligence, operational geology know-how and the ability to convey their acquired experience. It is a bottom-up model, according to the realities and needs of the country for a visible impact in sustainable development. In particular, it addresses the issue youth employment in the mining sector and proposes a solution for managing the development in the Artisanal and Small-scale Mining sector.
\end{abstract}

Keywords: Education - Training - Geology - Mining - Burkina Faso

\section{Introduction}

Higher education in West Africa in general faces a challenge with more and more young graduates seeking training that qualifies them for immediate employment adapted to the needs of employers, and this holds in particularly when teaching geosciences, especially in the mining sector.

In West Africa, the first difficulty for higher education, particularly in Francophone countries, is the ratio of students to lecturers exacerbated by the lack of adequate infrastructure and teaching human resources, all of which prevents the provision of quality theoretical and practical education.

The current role of the mining sector in the Burkina economy and its importance among development projects in the country require an increased knowledge of Burkina's geology and its georesources potential. This will be only achieved if more geologists and technicians are deployed and if they have the appropriate capacity and know-how; which in turn highlights the absolute need to train trainers who are well equipped to transmit this knowledge and know-how.

This article presents an innovative model which when implemented will be able to provide in the short and medium term the means to support high quality education and training in applied and practical geosciences. This model is responsive to job requirements, with a multidisciplinary and a networking approach for researchers, trainers and institutions for better training of students and promoting in-country scientific excellence.

Key points discussed in this presentation are:

- a review of education and training in the mining sector at the African, West African and Burkina Faso levels,

- the innovation model for education and training in the mining sector, as well as two examples of projects already designed for immediate implementation, and

- resulting benefits to the stakeholders in the field.

\section{Review on education and training in mining sector}

\subsection{International Canvas for Improvement of education and training in mining sector}

Several international institutions propose agendas for improving higher education in Africa in the field of earth sciences: 
(i) the African Mining Vision published by the United Nations Economic Comission for Africa (UNECA) in 2011 [1],

(ii) the UNESCO's Earth Science Education Initiative in Africa published in 2012 [2],

(iii) the WorldBank New Education Model for Africa in 2014 [3].

Their propositions are summarized in the table below (Table 1):

Table 1: Propositions for inmprovement of education and training in mining sector by the African Mining Vision Action Plan, UNESCO's Earth Science Education initiative in Africa and World Bank New Education Model for Africa.

\begin{tabular}{|c|c|c|}
\hline $\begin{array}{l}\text { African Mining Vision Action Plan } \\
\text { (2011) - at national level - }\end{array}$ & $\begin{array}{l}\text { UNESCO's Earth Science } \\
\text { Education Initiative } \\
\text { in Africa (2012) }\end{array}$ & $\begin{array}{l}\text { World Bank New Education Model } \\
\text { for Africa (2014) }\end{array}$ \\
\hline $\begin{array}{l}\text { Programme cluster } 2-\text { Geological and } \\
\text { mineral information systems } \\
\text { - promote collaboration between the } \\
\text { different national geological and mining } \\
\text { related institutions (Ministries, } \\
\text { Universities, Research Centres, etc). }\end{array}$ & $\begin{array}{l}\text { Build strong connections between } \\
\text { Industry and Universities }\end{array}$ & Link with the labor market \\
\hline $\begin{array}{l}\text { Programme cluster } 3 \text { - Building human } \\
\text { and institutional capacities } \\
\text { Diversify education, academic and } \\
\text { professional training funding sources to } \\
\text { include private sector; strengthen } \\
\text { continuing professional development } \\
\text { through short courses; align human } \\
\text { resources development to AMV policy } \\
\text { direction and needs of industry. }\end{array}$ & $\begin{array}{l}\text { Enhance multidisciplinary approaches in } \\
\text { research and teaching of Earth sciences }\end{array}$ & $\begin{array}{l}\text { Public-private partnerships help regional } \\
\text { member countries tap into the } \\
\text { experience, knowledge and financial } \\
\text { leverage of the private sector to develop } \\
\text { cutting-edge learning environments }\end{array}$ \\
\hline $\begin{array}{l}\text { Programme cluster } 6 \text { - Research and } \\
\text { development } \\
\text { Improve funding for minerals research } \\
\text { including focus on improved mineral } \\
\text { extraction processes as well as } \\
\text { environmental and social impacts. }\end{array}$ & $\begin{array}{l}\text { Reinvigorate old networks and build } \\
\text { new intra-African ones and between } \\
\text { African researchers and the global } \\
\text { research community }\end{array}$ & $\begin{array}{l}\text { Developing creativity and critical } \\
\text { thinking: Move away from a purely } \\
\text { classroom-based education model to } \\
\text { foster interaction and debate among } \\
\text { professors, students, young } \\
\text { entrepreneurs and businesses in Africa } \\
\text { and globally with a view to create a } \\
\text { culture of entrepreneurship and job-rich } \\
\text { growth. }\end{array}$ \\
\hline \multirow[t]{3}{*}{$\begin{array}{l}\text { Programme cluster } 8 \text { - Linkages and } \\
\text { diversification } \\
\text { Develop institutional arrangements that } \\
\text { combine the minerals industry, trade and } \\
\text { science, technology and innovation } \\
\text { complexes. }\end{array}$} & $\begin{array}{l}\text { Counter the lack of analytical facilities } \\
\text { through exchange, identification of } \\
\text { networks of expertise and obtaining new } \\
\text { equipment through new funding } \\
\text { mechanisms }\end{array}$ & $\begin{array}{l}\text { Participation: Engage key stakeholders } \\
\text { in developing strong education models } \\
\text { (parents, faculties, universities, science } \\
\text { academies, nongovernmental } \\
\text { organisations, civil society and } \\
\text { communities). }\end{array}$ \\
\hline & & $\begin{array}{l}\text { Evidence-based. Ensure that all } \\
\text { programs have a built-in impact } \\
\text { evaluation component to ensure that } \\
\text { they are results-based, focusing on } \\
\text { quality and learning outcomes. }\end{array}$ \\
\hline & & $\begin{array}{l}\text { ICT-based: Provide high-quality } \\
\text { education and tap into new learning } \\
\text { technologies }\end{array}$ \\
\hline
\end{tabular}

\subsection{Current West-Africa region projects in fostering earth sciences education and training}

The WAXI and GEOLOOC-WA projects had been launched and are ongoing prior even to the recommendations outlined above by international institutions.

GEOLogy Open Online Courses - West Africa (GEOLOOC-WA) project [4]. The goal of GEOLOOC-WA is to provide via internet solutions access to courses of a network of lecturers and researchers working in West Africa on topics related to the geology of the region. This site offers for example access to courses on African geology and associated disciplines such as good practices in exploration and exploitation of mineral resources and water, engineering geology, etc.

The expected results of this project are: 
- Intensification of academic exchanges between African Universities and International partners

- Establishment of leading centres in Africa for the development of on-line resources in geosciences

- Evolution of teaching practices and enhanced capacity for the delivery of high-level course content

- Reduction of discrimination and social or gender disparities for access to knowledge.

For the moment, this project has not had the uptake desired, because of the difficulties of having a stable and good internet connection in some countries of West Africa, the costs associated with creating new online content, and the still high cost of computer equipment for some students.

More information on GEOLOOC-WA is available on their website http://geolooc.net/

The West Africa eXploration Initiative (WAXI) project [4]. The WAXI project started in 2006 and still in progress (end of phase 3 in 2018) and is a large-scale public-private partnership involving five universities and ten national geological surveys or equivalents in West Africa. In the Capacity Building section of WAXI, it organizes a range of training opportunities for geologists. This component is divided into two components (1) training and technical support and (2) implementation and policy training. To date, WAXI has accompanied the honours, master's and doctorate graduation of more than 90 students as well as the professional training of hundreds of principally African geologists from mining companies, geological surveys and universities.

As a current review of WAXI, the scientific output of this initiative represents more than $10 \%$ of the last 5 years' publications on geology in West Africa. WAXI has also provided an improvement in the human, educational and logistical resources of certain West African universities and geological services.

More information about WAXI is available on the website http://www.tectonique.net/waxi3/

\subsection{Current model of earth sciences education and training in Burkina Faso}

In geosciences education and training in Burkina Faso, the initiating structure is the geology department of the University of Ouagadougou which is operational since the eighties. With the mining boom of the second half of the decade of 2000 , the demand for trained personnel in the mining sector has increased. With regard to the national regulatory requirements for the recruitment of nationals in the staff of exploration and mining companies, additional new public institutions such as National Engineers' School of Fada N'Gourma (ENSI Fada), actually institutionalized as an university and private schools such as Teng Tuuma Geoservices / Institut Teng Tuuma Geosciences of Ouagadougou (TTG / ITTGO) have been created.

At the university, the training curriculums, updated since 2011, are based on the Bachelor - Master - Doctorate (BMD) system. In geosciences, the courses bring together the fundamental theoretical and applied courses. However, with a heavy teaching load facing an overwhelming number of students [5], university lecturers and researchers do not have the time to organize applied training courses to meet the requirements of professionalization in mining geology. The students will only really learn the "job" in the context of internships or recruitments by mining companies, which are hard to obtain.

It is to overcome these handicaps that ENSI-Fada was created. It tries to provide to a limited number of students with more practical training in the field of exploration geology and mining in particular. The same is true for private training institutes whose high costs of education reduces the number of students.

All these establishments are confronted with a lack of adequate teaching tools, a small number of qualified trainers and, above all, a lack of awareness of the practices of mining geology. Most of these institutions use foreign or national external lecturers, all of which increase costs of the training program. Lack of logistical support includes difficulties to get to the field and get access to important industry-standard equipment. Drawing inspiration from the recommendations of international institutions and initiatives already underway, several avenues for development can be supported at the national level to improve the future of the geoscience training sector in Burkina Faso.

\section{A new model of training and collaboration in the mining sector}

Teng Tuuma Geoservices/Institut Teng Tuuma Geosciences of Ouagadougou and the NGO "Le Soleil dans la Main" are members of the consortium of organizations involved in WAXI and are therefore actors and beneficiaries of the success of this project. Thus, to push the implementation at the national level in Burkina Faso these two structures have joined forces to propose a new model of training and collaboration in the mining sector.

\subsection{Rail way anal ogy : explanation of the scheme}

This model presents the possibility of applying a new model of collaboration between the different actors of sustainable development in the field of applied geosciences. This is the necessary bridge between "Applied 
Research" and "Operational Geology", defined by the image of a 'railway' needed to move towards a general wellbeing from a starting situation not yet profitable to all. "Applied Research" and "Operational Geology" being the rails, they need sleepers to strengthen their connection. For this purpose, institutions such as the dedicated Ministries (Mines, Higher Education, Scientific Research and Innovation ...), Geological Surveys, Technical and Financial Partners (TFP), non-governmental organizations (NGOs) and civil society need to be involved in this process. We named this model of cooperation - collaboration: the analogy of rails and sleepers (Figure 1).

\section{Why rails and sleepers?}

- Rails, symbol of the common expression: "The train of development";

- Possibilities to support trains at different speeds on rails and with high passenger transport capacity symbolizing the stakeholders involved;

- Rails as a communication route with a long service life and with the least possible detours symbolizing the direct and safe way to follow;

- Rails as a mean of transporting large mining tonnages (symbolizing mines);

- Sleepers ensuring a strong cohesion of the two rails between them;

- Gravels deposited on rails symbolize geology: the rocks and minerals of natural resources;

- Railways with intermediate stations symbolize projects milestones.

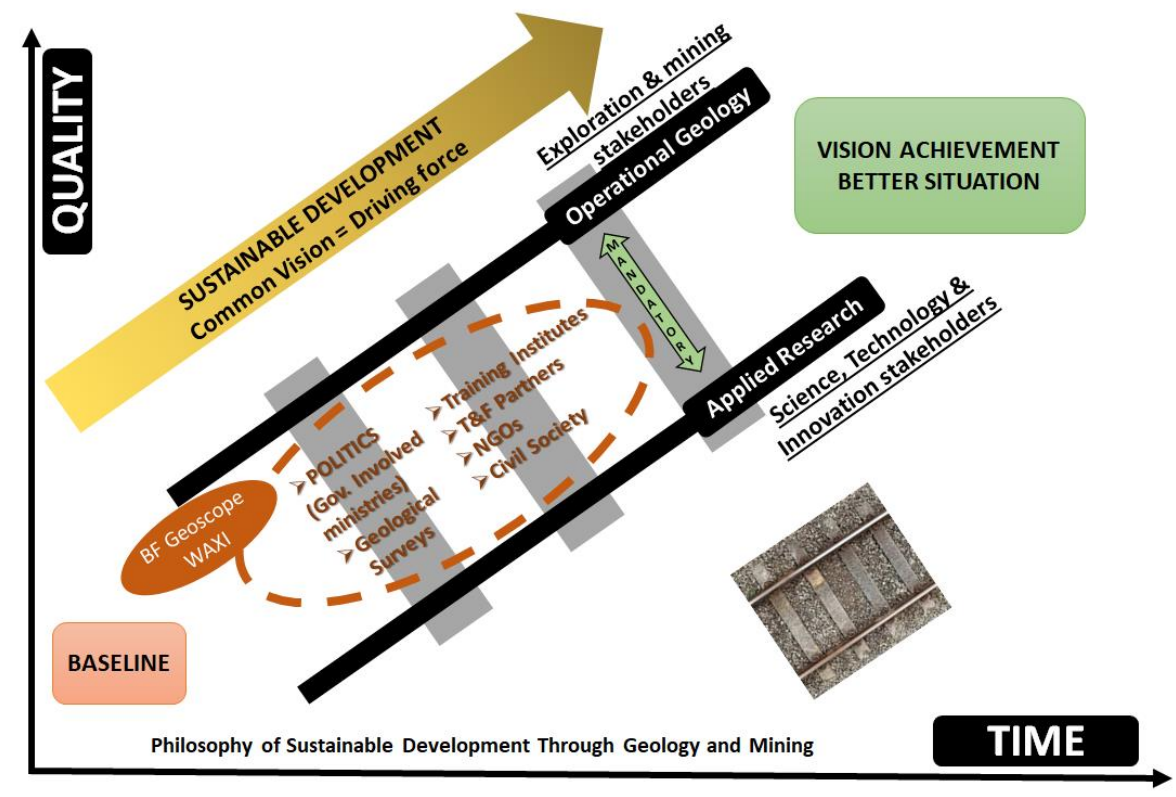

Figure 1: Railway analogy for sustainable development through innovation, geoscientific and technological knowledge related to exploration and mining

\subsection{Examples of projects responding to the model}

The railway analogy can apply to Burkina Faso's current situation:

1. Support the intended formalization of Artisanal and Small-scale Gold Mining (ASGM): ASGM monitoring and Small-scale mine managers Training Project.

2. Training of new doctoral students in geosciences capable of understanding the distribution of favorable areas for mineral exploration, as well as supporting the promotion of research professors from universities and higher institutes in geosciences: Burkina Faso Geoscope Project.

ASGM monitoring-Small-scale mine managers Training. In Burkina Faso, ASGM is parallel to the industrial exploitation by large-scale mines (LSM), and LSM gold has become the country's leading export product. Although it has a negative impact from a social point of view (drugs, insecurity, prostitution, child labor), health and environmental (use of mercury and cyanide in the treatment process), ASGM remains a direct source of income for tens of thousands of people and even more than a million if we include indirect effects. It is also the second source of employment for rural populations after agriculture. ASGM is a sort of "necessary nuisance" that needs to be better supervised to allow improved socio-economic benefits and sustainable development.

ASGM activity is currently effectively unregulated and dangerous, particularly with respect to environmental, health and social conflicts. One of the main origins of these problems is the actors' lack of appropriate skills. With training the trainers, we aim to provide people sensitized to best practice, including environmentally-friendly practices that lead to increased incomes of artisinal miners in Burkina Faso. 
According to the "railway" model, operational geology corresponds to the training of the actors in improved operating techniques, with a view to improved safety, and in adequacy with the sustainable development of the sector. Applied research (or Research-Action-Development), undertaken by academics, researchers and developers, will lead to a more holistic approach to the sociological, economic and technological aspects of understanding and better equipping the actors of the AGSM.

Curricula of the courses and training programs have already been established and will be validated subsequent to collegial consultations between the actors of ASGM: artisanal miners, the impacted communities, the public administrations, the Organizations of the Civil Society (CSO) and Non-Governmental (NGO) and industrial mining companies. The curricula contain, among other subjects, modules on the geology of mineral resources, drilling operations and retaining galleries, the management and use of explosives, environmental management, mining law, health and safety.

Courses and training programs, depending on the education level of students, lead to undergraduate certificates of capability or post-graduate Masters degrees in small-scale mine management.

Burkina Faso Geoscope [6]. As explained above (see part 2.3), Burkina Faso's Earth education and training system faces challenges in human [5], material and technical resources and there is a mismatch between research, training and jobs.

The Burkina Faso Geoscope project will support the training of at least four new PhDs in geosciences and support the promotion of lecturers and researchers from the partner universities and higher institutes in geosciences in order to mitigate the deficit in staff.

Specific objectives of this project are:

- Training the next generation of researchers in the field of applied metallogeny and mineral prospecting

- Develop teams and adequately equipped research groups for a center of excellence in geophysics and metallogeny in BF including the University of Ouagadougou, BUMIGEB (Burkina Geological Survey) and ITTGO

- Train researchers and trainers in best practices in the mining industry for the adequacy training employment

- Enhance a collaborative network between Burkina Faso and partners academics based on the existing WAXI network.

- Support ITTGO's ambition to become a center of excellence in metallogeny and mineral explorationable to support the training of engineers, geologists, technicians and other skilled personnel.

The Burkina Faso Geoscope project aims to address scientific objectives which have clear economic impacts. It will elaborate, test and apply new concepts of how to better explore large mineralizing systems in the volcanic and volcano-sedimentary terrains of southwestern Burkina Faso that can be transferred elsewhere in the world through the transfer of knowledge program foreseen in the framework of this project. This will lead to an improved understanding of the control of mineral deposits distribution, enhance rate of discovery via an improved predictive ability resulting in reduced technical risks for mineral explorers.

In this project, applied research will give, through the $\mathrm{PhDs}$ and their supervisors' research, a wealth of knowledge (including prospectivity guides, maps, etc.) able to improve operational geology.

Training of trainers at a high level $(\mathrm{PhD})$ able to understand the distributions of mineralization in favorable areas for exploration, which will help in the training of students in a more operational way for exploration and mining companies (LSM).

\subsection{Stakeholders benefits}

The railway model is collaborative, and all stakeholders should benefit from it, some of these benefits are presented below.

\section{Burkina Faso: Politics, Earth Sciences education and training, geological surveys.}

- Reducing the lack of lecturers and researchers in the domain of applied geoscience in Burkina Faso who are needed to train the next generations of underground resource managers.

- Construction of new development strategies based on adequate tertiary education models. It is a powerful tool in support of the United Nations Sustainable Development Goals, especially Goals 4 and 9 (Goal 4: Ensure inclusive and quality education for all and promote lifelong learning. Goal 9: Build a resilient infrastructure, promote sustainable industrialization and foster innovation)

- Creation of a pole of excellence in applied geology for exploration in Burkina Faso, to train engineers and technicians who intervene throughout the value chain from exploration/ extraction to post-mine rehabilitation.

- Help the formalization of ASGM. 


\section{Technical and financial Partners.}

- Funding of bottom-up projects which are relevant for country development.

- Technical assistance on projects.

\section{Training institutes - Universities.}

- International scientific collaboration agreements

- Better communication and support for scientific excellence according to desired thematics and sustainable development.

\section{Researchers and students.}

- Training and support for doctoral students.

- Valorization of applied research results in the field of geosciences.

- Better networking and involvement in exploration and mining strategies in Burkina Faso and around the world

- Realization of professional and personal projects in obtaining Bachelor, Master or Doctoral degrees in geosciences which integrate scientific research, all under optimal working conditions.

- Valorization of researchers' work and the results of doctoral research (applied research).

\section{NGOs and Civil Society.}

- Adequacy with the country's development prospects based on mining.

- Provision of qualified human resources and capacity building.

- Helping supported countries to fulfill Sustainable Development Goals.

\section{Mining companies.}

- Scientific benefits of their exploration and exploitation work, with the addition of refined and contextualized maps and prospectivity guides.

- Training and subsequent supply of qualified staff in minerals exploration through the 'training of trainers' component of this project.

- Contribution to their Corporate Social Responsibility (CSR) within the framework of the mining code (2015) in force in Burkina

\section{ASGM actors.}

- Formalization of their activity with respect to mining law

- Training in best practice, including environmental-friendly practices for improved incomes

\section{Summary and Conclusion}

Various models and recommendations for better education and training in Earth Sciences have been proposed by international institutions. We have focused on the mining sector, which accounts for a significant share of revenues for African states in general, and Burkina Faso in particular. After presenting projects already implemented, we presented the situation of higher education in mining geology in Burkina Faso. One of the problems is that training remains fairly general without providing students with the resources they need to become immediately operational for their potential employers, the exploration and mining companies. To limit this, we have proposed a model of education and training in mining geology in Burkina with its two entities ASGM and LSM (exploration and exploitation) and the knowledge that pertains to them.

ASGM's challenge remains the formalization of its practice and its supervision its practitioners. LSM's challenge is to have qualified and competent staff for their operations. The answer to these challenges can only lie in the application of new educational schemes such as the one of 'railway' linking Applied Research and Operational Geology. Training of trainers at all levels of education remains the key to solving this problem.

The 'railway' education and training model can only be done by trainers who have both mining intelligence (knowledge), operational geology know-how and the ability to convey their acquired experience (operationalization of learners).

The innovative character of the proposed model lies in the implementation of recommendations of international institutions in Burkina Faso, according to the realities and needs of the country to achieve a meaningful impact in sustainable development. In particular, it addresses the problem of youth employment in the mining sector and proposes a solution for a managed development of ASGM, both intellectual and technical. 


\section{References}

[1] African Union Commission : Action Plan for implementing the African Mining Vision, Building a sustainable future for Africa's extractive industry: From vision to Action, African Union Commission, Addis Ababa. 45 pp. (2011)

[2] UNESCO : UNESCO's Earth Science Education Initiative in Africa. 6 p., illus. (2012)

[3] World Bank and Elsevier : A Decade of Development in Sub-Saharan African Science, Technology, Engineering and Mathematics Research. 72 pp. (2014)

[4] Jessell M., Baratoux D., Siebenaller L., Hein K., Maduekwe A., Ouedraogo M. F., Baratoux L., Diagne M., Cucuzza J., Seymon A., Sow El H. : New Models for Geoscience Higher Education in West Africa. Journal of African Earth Sciences (Submitted)

[5] Siebenaller L., Hein K., Jessell M., Baratoux L. Challenges and successes in building geoscience capacity in West Africa. WAXI-2 Conference, Dakar (2015).

[6] Ouédraogo M. F., Siebenaller L., Toé W., Jessell M. Note conceptuelle de Projet Burkina Faso Geoscope. 18 p. (2017) 